\title{
Long-term population dynamics of breeding bird species in the German Wadden Sea area*
}

\author{
Gottfried Vauk ${ }^{1}$, Johannes Prüter ${ }^{1}$ \& Eike Hartwig ${ }^{2}$ \\ ${ }^{1}$ Norddeutsche Naturschutzakademie; Hof Möhr, D-3043 Schneverdingen, FRG \\ ${ }^{2}$ Institut für Naturschutz- und Umweltschutzforschung des Verein Jordsand; Wulfsdorf, \\ D-2070 Ahrensburg, FRG
}

\begin{abstract}
For no other group of organisms in coastal areas are there so exact and long-term data available as there are for seabirds. Since the beginning of the 20th century, documentation of population size, especially for species breeding in colonies from the groups gulls, terns and auks, is almost complete. These species act as bio-indicators, and data on fluctuations in their population size are useful as they reflect changes in the state of the marine ecosystem. The population development of some of these seabird species (Herring Gull, Guillemot, Common, Arctic and Sandwich Tern) from the German North Sea coast, which primarily feed on fish, is given. Common to all these species is an exponential increase in numbers in recent years (1970-1985). Possible causes for this development, e.g. pressure from enemies or competitors, availability of breeding places, anthropogenic stress and mortality factors, as well as the direct and indirect anthropogenic-influenced changes in the trophic system due to the increasing eutrophication of coastal waters, are evaluated. Signs of a collapse in the stocks of seabirds resulting from environmental pollution are discussed. Consequences resulting from the ecosystem changes, such as reduction of nutrient discharge into the North Sea and the expansion of biological monitoring, are described.
\end{abstract}

\section{INTRODUCTION}

One well-tried method of recording and comprehending long-term developments in the marine ecosystem is the continuous monitoring of the population dynamics of individual species or of entire biocoenoses as bioindicators. Indicators need to be welldocumented as to their position in the environment and it must be possible to carry out long-term monitoring of their population dynamics with relatively little trouble (Ellenberg, 1982). In this respect, the bird populations inhabiting the shallow waters of the southern North Sea coast and the adjacent sea areas have traditionally played a prime role (Tasker \& Pienkowski, 1987).

No other group of organisms in coastal areas has been as thoroughly investigated and as much turned to account from this particular angle as have the seabirds (Schulz, 1947; Hälterlein, 1986; Taux, 1986; Becker \& Erdelen, 1987; Vauk \& Prüter, 1987). Looked at from this point of view, the fact that many of the important seabird breeding grounds have been under the scrutiny of nature protection associations since the turn of

- Presented at the VI International Wadden Sea Symposium (Biologische Anstalt Helgoland, Wattenmeerstation Sylt, D-2282 List, FRG, 1-4 November 1988) 
the century is of inestimable value. This has made it possible to trace the population changes particularly of colony breeding seabirds back to the beginning of the present century.

The population figures available for the 19th century are sporadic and comparatively inexact; yet they suffice to show that the over-exploitation and ruthless persecution of the populations for commercial purposes had by the turn of the century led to the decimation of most seabird populations on the German coast (Thiessen, 1986; Vauk \& Prüter, 1987).

Since that time, as a response to this development, an increasing number of seabird conservation areas has been set up at the most important colony sites. As a consequence, the over-exploitation of the populations was curbed and the numbers recovered in varying degrees. Over and above this, the twenties and thirties witnessed the settlement of new and the reoccupation of former colony sites by several species, e.g. Lesser Blackbacked Gull (Larus fuscus), Blackheaded Gull (L. ridibundus) and Kittiwake (Rissa tridactyla) (Goethe, 1969; Prüter, 1983; Fleet, 1984).

Yet one cannot say that their development since that time has been undisturbed. The increase in the Herring Gull (Larus argentatus), for instance, very soon came to be considered too rapid, so that control measures were taken which reached a climax in the sixties and early seventies. At that time, these direct methods of seabird population management were also employed at a number of Black-headed Gull colonies on the German North Sea coast (Goethe, 1964 i Vauk \& Prüter, 1987).

The introduction of toxic substances (e.g. pesticides) into coastal waters of the southern North Sea was certainly a contributing factor in the renewed population declines of a number of seabird species in the fifties and sixties especially in terns (Koeman, 1975; Becker \& Erdelen, 1987; Schumann, 1987). The same is true of the expansion of tourism and other industries along the coast, which encroached on potential nesting-sites and even to some extent on established protected areas too.

Influenced by the beneficial effects of seabird protection efforts on the one hand and the pernicious workings of man on the other, population sizes of colony-breeding seabird species on the German North Sea coast in the middle of the century showed a number of different reactions. In the gulls the observed trends were of stagnation or slight increase (Becker \& Erdelen, 1987). The same was noted in the guillemots (Uria aalge) on Helgoland (Vauk-Hentzelt et al., 1986). In contrast, dramatic population collapses occurred among the terns (Thiessen, 1986).

\section{RESULTS}

In the following, we shall confine our attention to a number of colony-breeding, principally fish-eating species of seabirds from the group of families including the gulls, the terns and the auks. We shall describe their population developments using selected examples from a large number of studies (Vauk et al., 1989; Hartwig et al., 1989) and present possible explanations for the observed phenomena.

Our examples were chosen from these three groups because

- they are relatively common and constitute between them the bulk of the breeding birds in the southern North Sea,

- their total populations are the most thoroughly documented, and

- they are integrated in the marine ecosystem at the end of food-chains. 
What the example species also have in common is a sudden exponentially increasing population boom in the late sixties and seventies.

In the Herring Gull (Larus argentatus), an accelerating growth in the total population occurred in spite of massive control operations involving poisons, which reached a peak on the German North Sea coast in the sixties and seventies (Fig. 1). Despite such drastic measures, the existing large colonies (e.g. Mellum, Memmert, Trischen) continued to expand and new rapidly growing settlements were established (e.g. Juist, Spiekeroog). Whereas in 1969 the Herring Gull population of the German North Sea coast stood at about 17000 breeding pairs, by 1984 this figure had reached 45000 . In that year, nearly $90 \%$ of the total population bred in no more than seven super-colonies of more than 1000 pairs. In the same period, the population in the Netherlands grew from 17000 to about 90000 pairs (Vauk \& Prüter, 1987; Spaans, pers. comm.).

The population dynamics of the Kittiwake (Rissa tridactyla) on Helgoland, its sole breeding ground in the southern North Sea, can be traced with a high degree of accuracy: whereas the average growth in the sixties was $14 \%$ per annum, between 1970 and 1980 the figure increased to $22 \%$. The breeding population expanded during this time from 400 to 2350 pairs and by 1986 it had reached a total of 3310 pairs. Just recently, however, there have been signs that an upper limit is being approached (Fleet, 1984; Prüter, 1986; Voss et al., 1987).

Similarly, the Guillemots (Uria aalge) breeding on Helgoland have displayed an accelerated population increase in the last few years (Fig. 2). Between 1956 and 1969, the colony consisted of around 1000 pairs. A drop to about 800 pairs was noted in the midseventies but by 1985 the population had tripled its size to nearly 2500 breeding pairs (Vauk-Hentzelt et al., 1986).

Finally, the population dynamics of Common Tern (Sterna hirundo) and Arctic Tern (St. paradisaea) on the German North Sea coast display a very similar pattern (Fig. 3): a steep fall-off in the fifties and sixties followed by a rapid increase (Vauk \& Prüter, 1987). This phenomenon of expansion during the last few years has also been noted in the German North Sea population of the Sandwich Tern (St. sandvicensis) (Fig. 3). In the mideighties, this species actually reached its highest number of breeding pairs so far this century (Schumann, 1987). On the coast of the Netherlands too, after the low point in the sixties caused by human interference, observers report a steady increase in population once more (Bourne \& Vauk, 1988).

What emerges as a common factor in all these examples is basically a very surprising phenomenon: the breeding populations of gulls, terns and auks on the German North Sea coast have for the past 15 years all been following a remarkably similar pattern of steep to exponential growth. What is more, this is happening irrespective of whether a depleted population is on the way to recovery or a previously apparently stable population spontaneously begins to expand.

\section{DISCUSSION}

There are other examples - for instance the growth of the Cormorant (Phalacrocorax carbo) population in the North German coastal region (Knief \& Witt, 1984) or the settlement of the Fulmar (Fulmarus glacialis) and Razorbill (Alca torda) of the Helgoland seabird colonies in the seventies (Moritz, 1980; Vauk, 1985) - which suggest that on our 


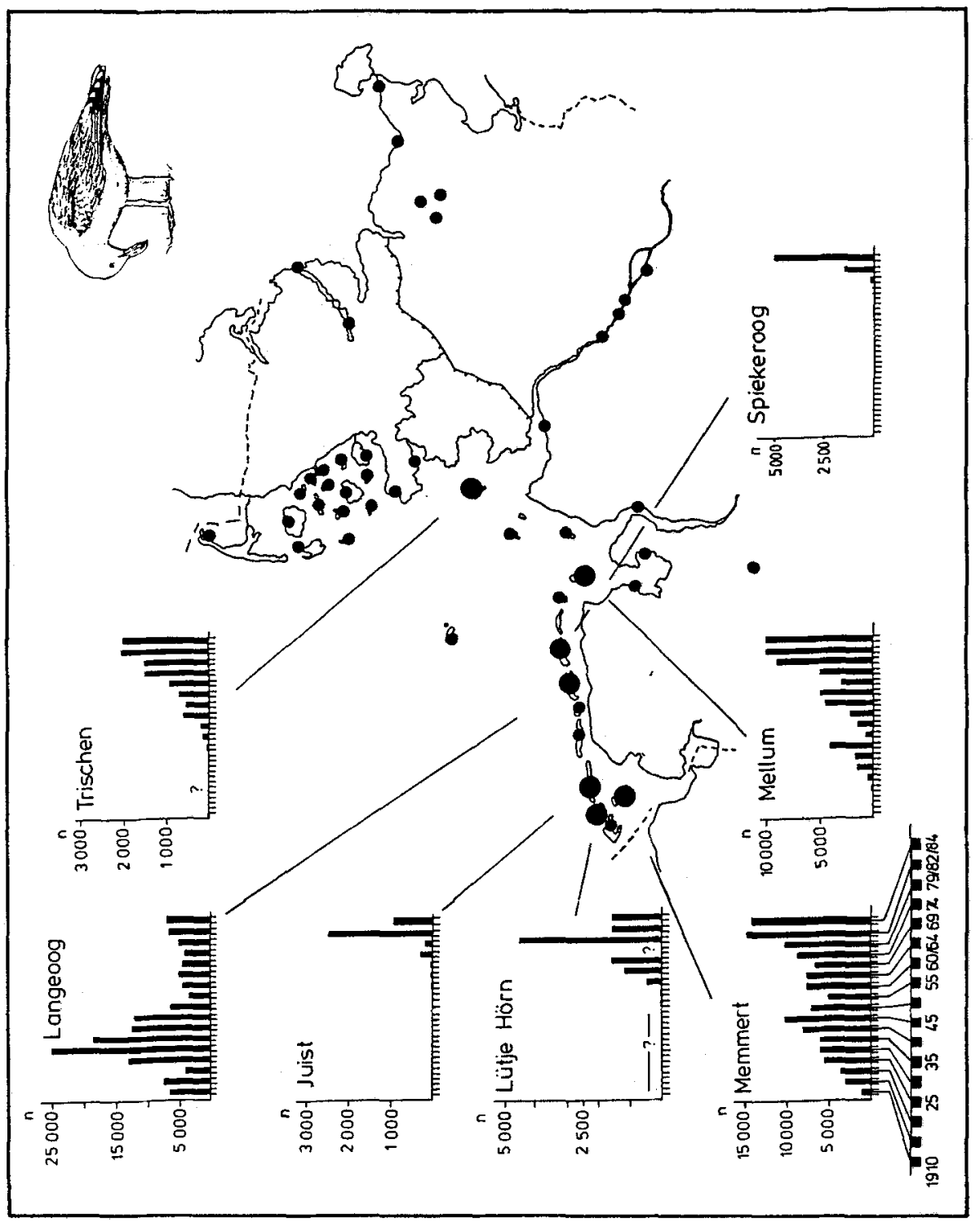

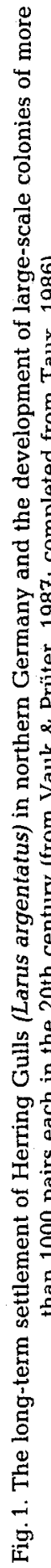




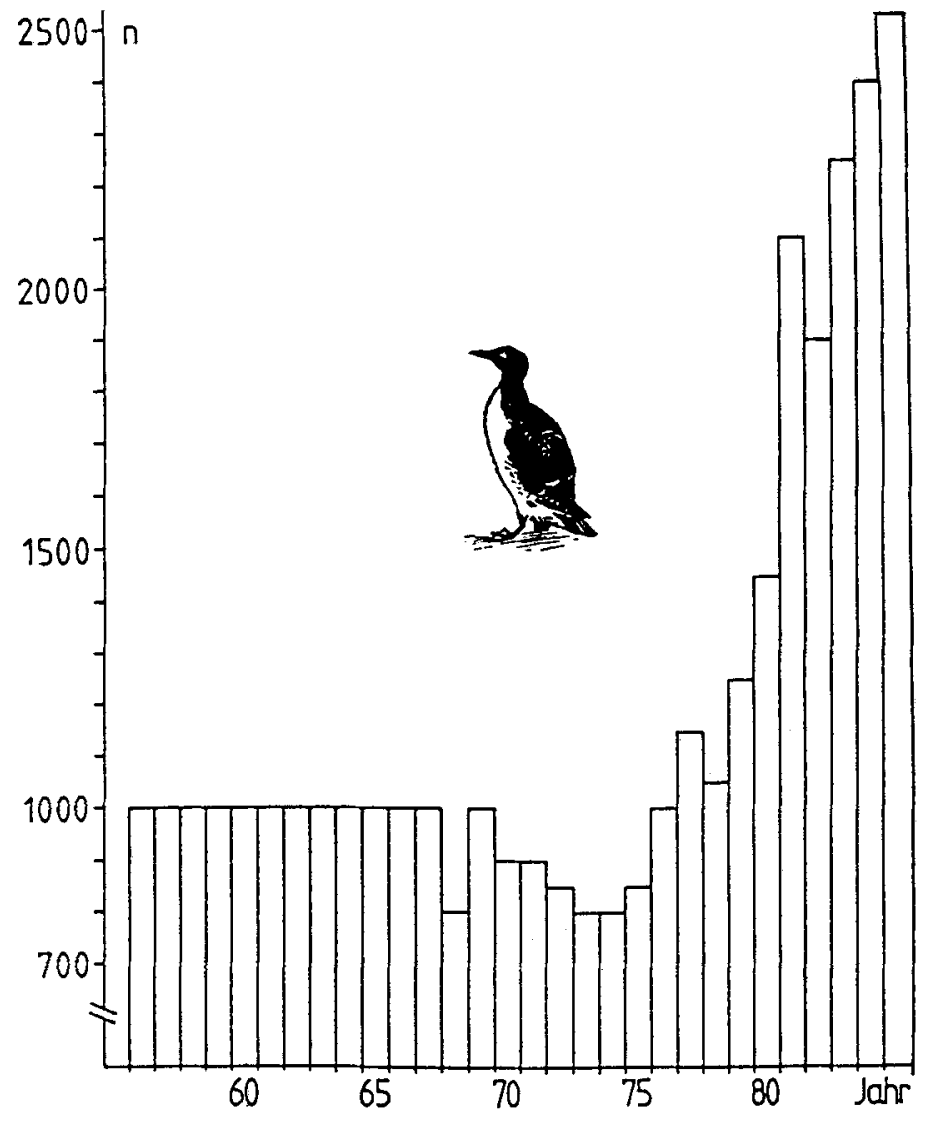

Fig. 2. Population changes of Guillemot (Uria aalge) on Helgoland from 1956 to 1985 (from VaukHentzelt et al., 1986; completed by reports from Verein Jordsand)

coasts the living conditions for primarily fish-eating seabirds are at present apparently excellent. Even the rapid increase in numbers of Gannets (Sula bassana) on passage off the German and Danish North Sea coasts can be interpreted in this light (Brunckhorst, 1985; Meltofte \& Faldborg, 1987).

Looking beyond the piscivorous seabirds, it may be as well to mention at this point that the breeding population of the Eider (Somateria mollissima), feeding exclusively on mussels, has also shown a rapid increase on the German North Sea coast since the seventies, a development bearing a striking resemblance to the patterns described above (Nehls, unpubl.).

Even today when it comes to questions as to the causes of these remarkable population dynamics, explanations going beyond mere suppositions are not forthcoming.

In the period of time in question, neither the pressure of natural enemies, competition, nor the availability of nesting sites or the disturbances and losses due to human interference have altered in any way which would explain this process. On the contrary, 


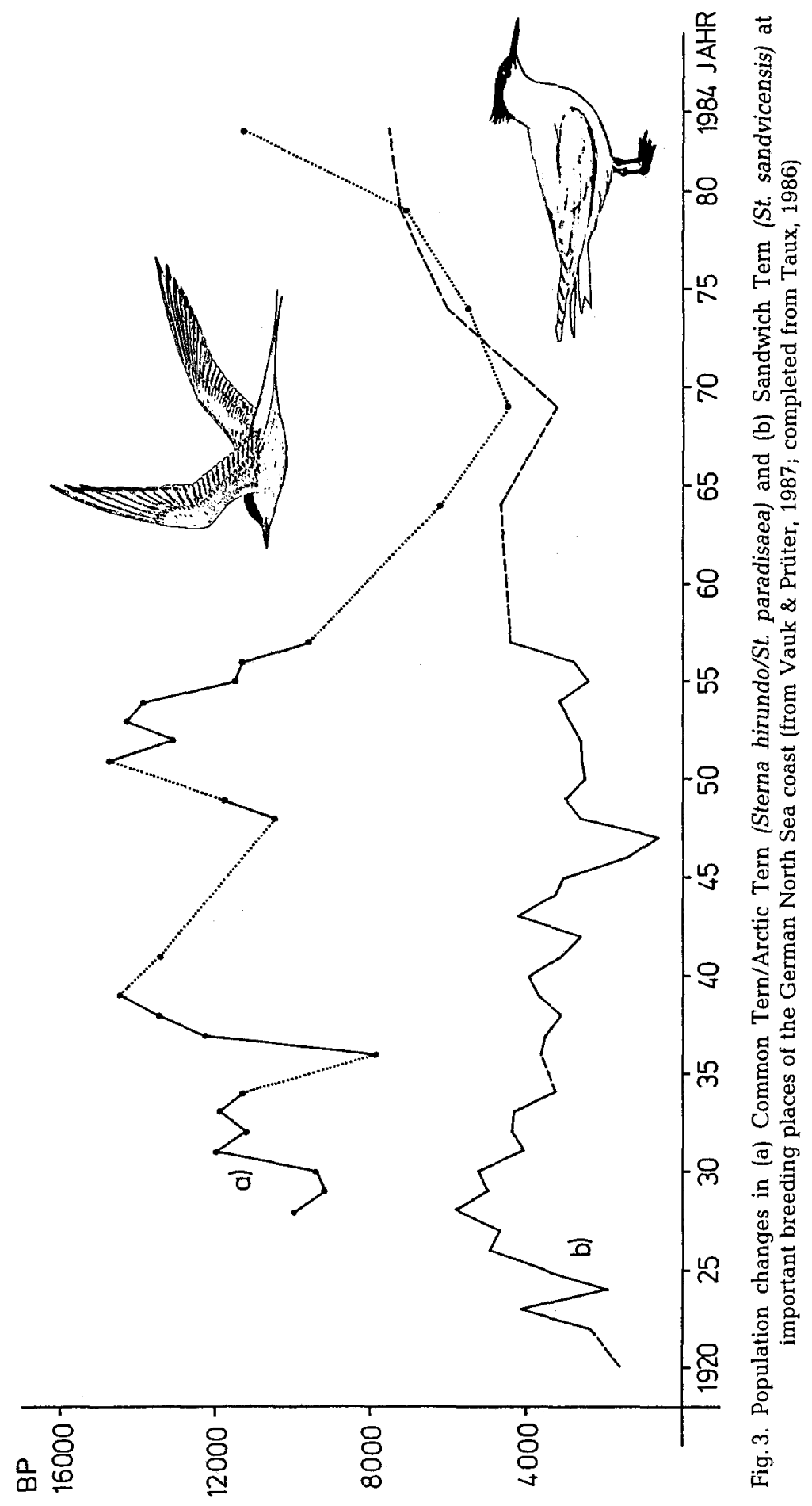


after the rapid increase in seabird losses at the beginning of the eighties due to the persistent oil-pollution of the coastal sea areas, for example, it would have been far more plausible to expect the exact opposite development in the populations of at least the most seriously affected species of seabirds (Vauk et al., 1987).

Other factors must be at work here, factors which within a very short time raised the capacity of the environment for the species in question.

In the past, food availability has often enough been identified and described as a very effective - and quick reacting - regulator of seabird populations (Furness \& Hislop, 1981; Monaghan \& Zonfrillo, 1986; Meltofte \& Faldborg, 1987; Pedersen \& Christophersen, 1987). Today it must be considered highly probable that the explanation of this simultaneous development in the Wadden Sea region of the south-eastern North Sea and in the sea areas beyond is to be found - in part at least - in a tremendously improved food-supply.

Long-term investigations into the feeding habits of large gulls in the Helgoland region have revealed that certain species of small fish (e.g. Ammodytes, Sprattus, Agonus) are present in these waters today in far greater quantities than they used to be even in the late sixties (Prüter, 1988, 1989). Net-content analyses carried out by the German shrimp fisheries confirm that in particular parts of the sand flats the populations of certain species of fish important for seabird nutrition are on the increase (Tiews, 1983).

As to the possible causes of these developments, it must once again be considered very probable that human interference in the marine environment contribute - directly or indirectly - to these changes in the trophic system (van Impe, 1985). The impact of the fishing industry on the quantitative balance between fish species in a particular region can be enormous (Hempel, 1978). Even more important in this respect, however, seems to be the problem complex associated with the advancing eutrophy of coastal waters (Gerlach, 1987).

Changes which have been recorded in the quantity and nature of phytoplankton in the southern North Sea must be seen in association with the increasing amounts of nutrients introduced into these waters (Radach \& Berg, 1986). It must be assumed that these changes set up reactions whose effects extend to the highest levels of the trophic system.

If it is indeed the case that the on-going changes in seabird populations on the German North Sea coast are the result of a basically unnatural expansion of capacity, then there are definite reasons for concern with respect to future developments. A collapse of the populations resulting from overloading the marine ecosystem cannot apparently be ruled out, even for the near future.

Examples of such developments have become increasingly common recently. Take for instance the dramatic drop in the populations of cliff-breeding seabirds in North Norway and on the Shetlands (Heubeck, 1988; Prüter \& Vauk, 1988) - in this case the prime cause is probably over-fishing of the feeding grounds - or the sudden rapid decline in the populations of larger gulls in the north of Great Britain (Lloyd, 1987).

What action is called for, then, on the basis of these considerations?

First and foremost, of course, the unnaturally high level of nutrients being introduced into the North Sea must be reduced and if possible cut out altogether, without waiting for the definitive proof of whether these present prognostications are indeed correct!

Another urgent requirement is the intensification of biological monitoring, so as to 
prevent, as far as possible in the future, a repetition of the present situation whereby sudden developments like those in the cases described above take everybody unawares and almost totally unprepared.

A fine network of research projects is needed in order to trace long-term changes affecting marine organisms. Further, much closer collaboration is called for between the different disciplines of marine ecology. The tradition of very narrow specialization and compartmentalization must give way to a more critical overall view. In the marine ecosystem, birds are frequently at the end of food-chains and a glance at their population figures may very well provide the marine ecologists with valuable leads. Equally, without detailed knowledge of changes in the lower levels of the trophic system, it is hardly possible to understand fluctuations in seabird populations.

\section{LITERATURE CITED}

Becker, P. H. \& Erdelen, M., 1987. Bestandsentwicklung von Brutvögeln der deutschen Nordseeküste 1950-1979. - J. Orn. 128, 1-32.

Boume, W. R. P. \& Vauk, G., 1988. Human impact upon North Sea birds. In: Pollution of the North Sea, an assessment. Ed. by W. Salomons, B. L. Bayne, E. K. Duursma \& U. Förstner. Springer, Berlin, 579-595.

Brunckhorst, H., 1985. Das heutige Vorkommen des Baßtölpels Sula bassana bei Helgoland. Seevögel 6,60-62.

Ellenberg, H., 1982. Was ist ein Bioindikator? - Sind Vögel Bioindikatoren? - Seevögel (Sonderbd) 1982, 153-158.

Fleet, D., 1984. Changes in the numbers of breeding Kittiwakes in Helgoland. - Ringing Migration 5, 32-34.

Furness, R. W. \& Hislop, J. R. G., 1981. Diets and feeding ecology of Great skuas Catharacta skua during the breeding season in Shetland. - J. Zool. Lond. 195, 1-23.

Gerlach, S. A., 1987. Pflanzennährstoffe und die Nordsee - ein Überblick. - Seevögel 8, 49-62.

Goethe, F., 1964. Lenkung der Möwenbestände an der deutschen Nordseeküste mit Hilfe der Einschläferung erwachsener Möwen durch Glucochloralose. - Ber. dt. Sekt. int. Rat Vogelschutz $4,53-57$.

Goethe, F., 1969. Zur Einwanderung der Lachmöwe, Larus ridibundus, in das Gebiet der deutschen Nordseeküste und ihrer Inseln. - Bonn. zool. Beitr. 20, 164-170.

Hälterlein, B., 1986. Laro-Limikolen-Brutbestände an der schleswig-holsteinischen Nordseeküste 1983-1985. - Corax 11, 332-398.

Hartwig, E., Köth, T., Prüter, J., Schrey, E., Vauk, G. \& Vauk-Hentzelt, E., 1989. Seevögel. - In: Warnsignale der Nordsee - Wissenschaftliche Fakten. Ed. by J. Lozan \& H. v. Westernhagen. Parey, Hamburg (in press).

Hempel, G., 1978. North Sea fisheries and fish stocks - A review of recent changes. - Rapp. P.-v. Réun. Cons. int. Explor. Mer 173, 145-167.

Heubeck, M., 1988. Shetlands seabirds in dire straits. - BTO News 158, 1-2.

Impe, J. van, 1985. Estuarine pollution as a probable cause of increase of estuarine birds. - Mar. Pollut. Bull. 16, 271-276.

Knief, W. \& Witt, H., 1984. Zur Situation des Kormorans in Schleswig-Holstein und Vorschläge für seine künftige Behandlung. - Ber. dt. Sekt. int. Rat Vogelschutz 23, 67-79.

Koeman, J. H., 1975. The toxicological importance of chemical pollution for marine birds in the Netherlands. - Vogelwarte 28, 145-150.

Lloyd, C., 1987. Scotland's seabirds come out on top. - Scott. Bird News 8, 6-7.

Meltofte, H. \& Faldborg, J., 1987. Forekomsten af måger og terner på Blåvandshuk 1963-1977. Dansk orn. Foren. Tidsskr. 81, 137-166.

Monaghan, P. \& Zonfrillo, B., 1986. Population dynamics of seabirds in the Firth of Clyde. - Proc. R. Soc. Edinb. (B) $90,363-375$. 
Moritz, D., 1980. Das Brutvorkommen des Eissturmvogels (Fulmarus glacialis) auf Helgoland, Angew. Orn. 5, 149-177.

Pedersen, J. S. \& Christophersen, H., 1987. Søkongen Alle alle og dens forekomst i Sydskandinavien 1978-1986. - Pelagicus 2, 11-16.

Prüter, J., 1983. Bestandsentwicklung und Durchzug der Heringsmöwe (Larus fuscus) in der Deutschen Bucht. - Seevögel 4, 29-35.

Prüter, J., 1986. Untersuchungen zum Bestandsaufbau und zur Ökologie der Möwen (Laridae) im Seegebiet der Deutschen Bucht. Diss., Univ. Hannover, 142 pp.

Prüter, J., 1988. Weitere Untersuchungen zur Ernährung von Mantelmöwe (Larus marinus) und Silbermöwe (Larus argentatus) bei Helgoland im Winterhalbjahr. - Seevögel 9 (Sonderbd), 79-91.

Prüter, J., 1989. Phänologie und Ernährungsökologie der Dreizehenmöwen-(Rissa tridactyla-)Brutpopulation auf Helgoland. - Ökol. Vögel 11 (in press).

Prüter, J. \& Vauk, G., 1988, Katastrophaler Zusammenbruch der Lummenbestände in NordNorwegen. - Nieders. Jäger 33, 709.

Radach, G. \& Berg, H., 1986. Trends in den Konzentrationen der Nährstoffe in der Helgoländer Bucht (Helgoland-Reede-Daten), - Ber. Biol. Anst. Helgoland 2, 1-65.

Schulz, H., 1947. Die Welt der Seevögel. Lettenbauer, Hamburg, 260 pp.

Schumann, K., 1987. Zug und Rast der Brandseeschwalbe (Sterna sandvicensis) auf Helgoland in den Jahren 1969-1983. - Seevögel 8, 1-4.

Tasker, M. L. \& Pienkowski, M. W. (Eds), 1987. Vulnerable concentrations of birds in the North Sea. Nature Conservation Council, Aberdeen, $39 \mathrm{pp}$.

Taux, K., 1986. Brutvogelbestände an der deutschen Nordseeküste im Jahre 1984. - Seevögel 7, 21-31.

Thiessen, H., 1986. Zur Bestandsentwicklung und Situation von Möwen Laridae und Seeschwalben Sternidae in Schleswig-Holstein - sowie Gedanken zum "Möwenproblem". - Seevögel 7, 1-12.

Tiews, K., 1983. Über die Veränderungen im Auftreten von Fischen und Krebsen im Beifang der deutschen Garnelenfischerei während der Jahre 1954-81. - Arch. FischWiss. 34 (Beih. 1), 1-156.

Vauk, G., 1985. Naturdenkmal Lummenfels Helgoland. Niederelbe-Verl., Otterndorf, 104 pp.

Vauk, G. \& Prüter, J., 1987. Möwen-Arten, Verbreitung, Bestände, Probleme. Niederelbe-Verl., Otterndorf, $304 \mathrm{pp}$.

Vauk, G., Prüter, J. \& Hartwig, E., 1989. Die aktuelle Bestandszunahme der Seevögel - Ausdruck verbesserter Lebensbedingungen in der Deutschen Bucht? - NNA-Ber. 2 (1), 58-62.

Vauk, G, Dahlmann, G., Hartwig, E., Ranger, J. C., Reineking, B., Schrey, E. \& Vauk-Hentzelt, E., 1987. Recording of oil victims on the German North Sea coast, including research for the establishments of the cause. - Umweltbundesamt-ForschBer 87-041, 1-77.

Vauk-Hentzelt, E., Schrey, E. \& Vauk, G., 1986. Bestandsentwicklung der Trottellumme (Uria aalge) auf Helgoland 1956-1984. - Seevögel 7, 40-45.

Voss, M., Hartwig, E. \& Vauk, G., 1987. Untersuchungen zum Nahrungsverbrauch der Dreizehenmöwe (Rissa tridactyla) auf Helgoland an handaufgezogenen Jungtieren. - Seevögel 8, 5-13. 